\title{
FACTORS AFFECTING REVENUE LEVEL OF RUBBER FARMERS (Case Study at Musi Banyuasin, South Sumatra, Indonesia)
}

\author{
Iman Satra Nugraha \\ Balai Penelitian Sembawa, Pusat Penelitian Karet \\ Jalan Raya Palembang - Pangkalan Balai KM. 29, PO BOX 1127 Palembang, Indonesia \\ *corresponding author: iman_satra@yahoo.com
}

\begin{abstract}
Musi Banyuasin is a district which has the potential of rubber plantations, oil and gas companies. Corporate responsibility is one of them is to develop the area around the company's operations. This study aims to determine the factors that affecting the income of farmers program and non-program in the area of company operations. Respondents were chosen purposively to the rubber farmers who divided in two categories, in this case 50 respondents by program and non-program. Data collection used interview method with questionnaire. Data were analyzed quantitatively. The results showed that all variables significantly affect to the farmers' income at a real level of $12 \%$. It is seen significance value $0.000<\alpha 12 \%$. The variables that affect the farmer's income of the program $\left(\mathrm{X}_{2}\right)$, The farmers' rubber program price $\left(\mathrm{X}_{4}\right)$, the total production farmers program $\left(\mathrm{X}_{6}\right)$, and the amount of non-program farmer's rubber production $\left(\mathrm{X}_{7}\right)$. Total Revenue farmers program IDR 3,700,000 per month and rubber farming activities contribute to revenue as much as IDR 2,800,000. While the total revenue from non-program farmers is equal IDR 2,779,000 per month and rubber farming activities contribute to revenue as much as IDR $1,820,000$ per month.
\end{abstract}

Keywords: Revenue, Rubber, Factors, Farmers

http://dx.doi.org/10.21776/ub.agrise.2019.019.3.6

Received 27 April 2019

Accepted 02 August 2019

Available online 25 August 2019

\section{INTRODUCTION}

Rubber is one of the leading commodities in the province of South Sumatra besides palm oil. The large area of rubber plantations in South Sumatra is 838,749 hectares. The area consists of smallholder plantations is about 791,187 hectares, state plantations amounting to 11,334 hectares and private plantations amounting to 36,228 hectares and absorbing quite a large number of workers, namely 463,568 households (Direktorat Jenderal Perkebunan, 2016). The productivity of South Sumatra's plantations is still low because the used of clonal seeds 59.2\% (Syarifa, Agustina, Nancy, \& Supriadi, 2012).Increased awareness of using superior seeds is needed to be able to increase productivity.
Musi Banyuasin Regency has the largest rubber plantation area in South Sumatra, covering an area of 132,524 hectares (Direktorat Jenderal Perkebunan, 2015) so that these commodities make the main commodity for the Musi Banyuasin community very much. In addition, Musi Banyuasin has a non-agricultural company, namely oil and gas. Although rubber farmers coexist with oil and gas companies, the income level of rubber farmers is one of them strongly influenced by the price movements of rubber itself (Siburian, 2012). If the price of rubber is not stable then the income of rubber farmers is also unstable, but there is besides the price of rubber which can affect farmers' income. One form of corporate responsibility towards the surrounding environment 
is to create a program for fostering rubber farmers as done by company $\mathrm{X}$. The $\mathrm{X}$ company fosters rubber farmers around its operational area. Based research by Widyasari \& Rinojati, (2014), they are said the training is carried out because the level of knowledge of rubber farmers and adoption of rubber technology is relatively low. Therefore, the authors explain the factors that can affect the revenue of farmers by program and non-program and to see the average revenue received by farmers, both program farmers and non-program.

\section{RESEARCH METHODS}

The study was conducted in 2017 using respondents as many as 50 respondent. The selection of respondents was done intentionally by considering rubber farmers who had produced and participated in the plantation development program of the company (X company development farmers while farmers who did not participate in the rubber plantation development program were also operating in oil and gas companies. There were five villages which were the research locations Macang Sakti Village; Lubuk Bintialo; Pangkalan Bulian; Tampang Baru and Sukamaju. The five villages are built by X Company. Each farmer program and non-program sample were 50 respondents. The data used were primary and secondary data. Primary data is obtained by using structured interviews using questionnaires, while secondary data is obtained from literature studies (LIPI, 2014b). Data collection uses interview methods with structured questionnaires and processing data qualitatively and quantitatively. Revenue is the difference between revenue and costs incurred (Soekartawi, 1995). Mathematically it can be written as follows:

$$
\begin{aligned}
& \pi=T R-T C \\
& \Pi=(\mathrm{P} \times \mathrm{Q})-(\mathrm{TFC}+\mathrm{TVC})
\end{aligned}
$$

Where:

$$
\begin{aligned}
\Pi= & \text { Farmer income (IDR) } \\
\mathrm{TR}= & \text { Total revenue generated from farming } \\
& (\text { IDR }) \\
\mathrm{TC}= & \text { Total costs incurred from farming activities } \\
& (\mathrm{IDR}) \\
\mathrm{P}= & \text { Commodity price of the business (IDR / } \\
& \text { Kg) } \\
\mathrm{Q}= & \text { Number of commodities produced (kg) } \\
\mathrm{TFC}= & \text { Total fixed costs incurred in farming } \\
& \text { activities (IDR) }
\end{aligned}
$$

TVC = Total variable costs incurred in farming activities (IDR)

While the variables to find out the factors that influence the level of income of farmers are 11 variables. The liner regression model is formulated as follows:

$$
\mathrm{Y}: \mathrm{c}+\mathrm{ax} \neg 1+\mathrm{bx} \neg 2+\mathrm{cx} \neg 3+\ldots \ldots . \mathrm{nxn}+\varepsilon . .(3)
$$

Where:

$\mathrm{Y}=$ Rubber farmer income (IDR / month)

$\mathrm{C}=$ constant

$\mathrm{X} 1=$ Age of farmer $(\mathrm{yr})$

$\mathrm{X} 2$ = Number of rubber stands farmer program (tree / hectares)

$\mathrm{X} 3=$ Number of rubbers stands non program(tree/hectares)

$\mathrm{X} 4=$ Rubber price of farmer program (IDR $/ \mathrm{kg}$ )

$\mathrm{X} 5=$ Rubber price of farmer non-programmed (IDR / kg)

$\mathrm{X} 6=$ Total production of the farmer program $(\mathrm{kg}$ / month)

$\mathrm{X} 7=$ Total production of farmer non-program $(\mathrm{kg}$ / month)

$\mathrm{X} 8$ = Farming fertilization of farmer program (app / yr)

X9 = Farming fertilizing farmer non-program (app / yr)

$\mathrm{X} 10=$ Rubber tapping system of farmer program (app / week)

$\mathrm{X} 11$ = Rubber tapping system of farmer non program (app / week)

To get a good model, the variable should be free from multicollinearity, autocorrelation and heteroscedasticity. After the variable has been freed from these properties, it is necessary to test the model parameters and variable parameters (Nazir, 2005). Testing the model parameters (Test F) aims to see whether the independent variables used together have a significant effect on the dependent variable (Sudrajat, 1985). The statistical test used is the $\mathrm{F}$ test. Testing variable parameters ( $\mathrm{t}$ test) aims to determine whether the regression coefficients of each independent variable (X) used have a significant effect on the dependent variable (Y) (LIPI, 2014a). The statistical test used is the $t$ test and significant with a $12 \%$. 
Factors Effecting Revenue Level of Rubber Farmers

RESULTS AND DISCUSSION

Description of rubber farmers

Musi Banyuasing is a district that is quite extensive in the area of rubber plantations. But it is not supported by a high level of education. based on Table 1 the majority of rubber farmers in the study locations were elementary school graduates of $56 \%$. While the age level of farmers is still productive, namely $25-40$ years reaching $56 \%$ and farmers who are above 58 years only at $8 \%$. This condition can be said that farmers still have the power to build a more optimal rubber plantation. The average experience of $0-10$ year rubber gardening farmers is $44 \%$. The long experience of rubber gardening is because farmers already know and do rubber cultivation both at the age of 15 years.

Table 1. Description of rubber farmers

\begin{tabular}{|c|c|c|c|}
\hline No & Characteristic & Description & Percentage $(\%)$ \\
\hline \multirow[t]{3}{*}{1} & Education & Elementary School & 56 \\
\hline & & Junior High School & 22 \\
\hline & & Senior High School & 22 \\
\hline \multirow[t]{3}{*}{2} & Age & $25-40$ & 56 \\
\hline & & $41-55$ & 36 \\
\hline & & $>56$ & 8 \\
\hline \multirow[t]{3}{*}{3} & Rubber Farmer Experience & $0-10$ & 44 \\
\hline & & $11-20$ & 36 \\
\hline & & $>21$ & 20 \\
\hline
\end{tabular}

\section{Factors that affect farmers' income}

There are eleven variables that are thought to affect the income of independent smallholders and program farmers in the operational area of the oil and gas companies in Musi Banyuasin. The selection was made based on observations in the field, there were differences made during the process of rubber farming activities and from previous studies (Diantoro, Sunarsih, \& Soejono, 2009). These variables can affect the increase in farmer's income (Mepriyanto, Firdaus, \& Huda, 2015; Septianita, 2009).
Based on the analytical tool used eight independent variables which can be analyzed further to determine the effect of these variables on farmer income both program and self-help (nonprogram). Variables that cannot be included in the model are $\mathrm{X}_{3}, \mathrm{X}_{9}$, and $\mathrm{X}_{11}$. The variables are constants or have missing correlations.

Based on the eight variables performed multiple regression analysis shows that all variables affect the dependent variable (income). The results of the analysis can be seen in Table 2 .

Table 2. Analysis result

\begin{tabular}{|c|c|c|c|c|c|}
\hline Model & $\mathrm{R}$ & R Square & Adjusted R Square & $\begin{array}{l}\text { Std. Error of the } \\
\text { Estimate }\end{array}$ & Durbin-Watson \\
\hline 1 & $.92^{\mathrm{a}}$ & .84 & .81 & 790832.81 & 2.09 \\
\hline \multicolumn{6}{|c|}{ a. Predictors: (Constant), X10, X2, X1, X4, X7, X8, X6, X5 } \\
\hline b. Depen & ble: Y & & & & \\
\hline
\end{tabular}

Table 2 shows that all variables can explain that there is an influence on income of $84 \%$ while $16 \%$ is explained outside the variable that is set. In addition, the variables are free from the autocratic nature, which can be seen from the Durbin-Watson value of 2.095. Based on the results of ANOVA analysis shows that the model obtained as a whole has a significant effect on the income of independent smallholders and programs. This can be seen in the significance value smaller than $\alpha$ $12 \%$. The results of ANOVA analysis can be seen in Table 3. 
Table 3. Anova analysis results

\begin{tabular}{llrcrcc}
\hline & Model & \multicolumn{1}{c}{ Sum of Squares } & Df & Mean Square & F & Sig. \\
\hline 1 & Regression & 142058460421080.75 & 8 & 17757307552635.09 & 28.39 &, $000^{\mathrm{b}}$ \\
& Residual & 25642078158919.21 & 41 & 625416540461.44 & & \\
Total & 167700538579999.97 & 49 & & &
\end{tabular}

a. Dependent Variable: Y

b. Predictors: (Constant), X10, X2, X1, X4, X7, X8, X6, X5

Based on the results of the t-test analysis there are four variables that have a significant effect on the income of self-help rubber farmers and programs at a significant level of $10 \%$. The results of the $t$ test analysis can be seen in Table 4 .

Table 4. Coefficients analysis results

\begin{tabular}{|c|c|c|c|c|c|c|}
\hline & \multirow[t]{2}{*}{ Model } & \multicolumn{2}{|c|}{ Unstandardized Coefficients } & \multirow{2}{*}{$\begin{array}{c}\begin{array}{c}\text { Standardized } \\
\text { Coefficients }\end{array} \\
\text { Beta }\end{array}$} & \multirow[t]{2}{*}{$\mathrm{t}$} & \multirow[t]{2}{*}{ Sig. } \\
\hline & & $\mathrm{B}$ & Std. Error & & & \\
\hline \multirow[t]{10}{*}{1} & (Constant) & -608366301 & 1386387.29 & & -4.38 & .00 \\
\hline & $\mathrm{X} 1$ & -2971.19 & 17491.45 & -.01 & -.17 & .86 \\
\hline & $\mathrm{X} 2$ & 943.51 & 601.30 & .10 & 1.56 & .12 \\
\hline & $\mathrm{X} 4$ & 723.02 & 181.54 & .41 & 3.98 & .00 \\
\hline & $\mathrm{X} 5$ & 13.33 & 234.79 & .00 & .05 & .95 \\
\hline & X6 & 3772.10 & 762.08 & .44 & 4.95 & .00 \\
\hline & $\mathrm{X} 7$ & 6304.61 & 1476.10 & .34 & 4.27 & .00 \\
\hline & $\mathrm{X} 8$ & 125385.60 & 195094.05 & .04 & .64 & .52 \\
\hline & $\mathrm{X} 10$ & -80086.81 & 225340.96 & -.02 & -.35 & .72 \\
\hline & pendent Vari & & & & & \\
\hline
\end{tabular}

The variables that have significant effect are:

1) Number of rubber stands of farmer program $\left(\mathrm{X}_{2}\right)$

The number of rubber stands of farmers program has a significant effect on income, this can be seen from the significance value smaller than the significant level of $12 \%$. The average number of stands carried out by the program farmers has applied the spacing according to the recommendation when training in rubber cultivation, which is using a spacing of $6 \mathrm{~m} \times 3 \mathrm{~m}$ (Saptabina Usatani Karet Rakyat, 2012). The number of stands of rubber trees for farmers is higher than for non-program farmers. One of the differences is caused by the farmers' program to control diseases that can kill rubber plants (Fairuzah, Dalimunthe, Karyudi, Suryaman, \& Widhayati, 2014). Whereas independent smallholders use the interrupted crop on average which causes JAP so that many plants die (Nugroho, Istianto, Fairuzah, \& Karyudi, 2009).

Agricultural Socio-Economics Journal
The condition of the farmer's program can be seen in Figure 1.

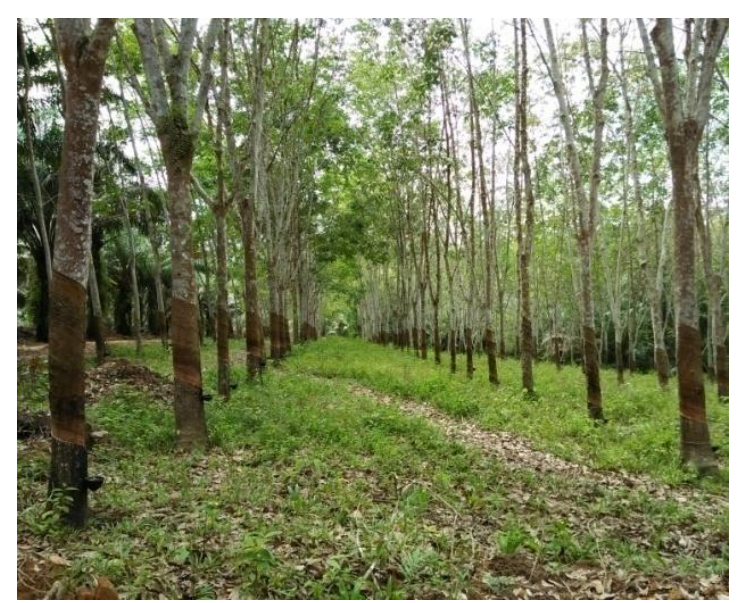

Figure 1. Rubber farming condition of program

It can be seen in Figure 1 that the condition of the program farmers' farms is very well maintained, visually the garden looks clean because weed control is still done, the rubber plants use the 
Factors Effecting Revenue Level of Rubber Farmers

spacing according to the recommendation of $6 \mathrm{mx}$ $3 \mathrm{~m}$ and the tapping field is good.

\section{Rubber price of farmer program $\left(\mathrm{X}_{4}\right)$}

The price of farmer's rubber program is a variable that influences the income of farmers because of it (Mepriyanto et al., 2015; Pasaribu, 2017). The price of farmers' rubber program is higher than the price of rubber received by non-program farmers. The difference is due to the farmers' rubber processing system in accordance with the recommendations, namely not soaked, using ant acid freeze and selling rubber in groups (A, Dompak, \& Suprayitno, 2006; Agustina, Syarifa, \& Nancy, 2013; Alamsyah, Nugraha, Agustina, \& Vachlepi, 2017; Wiyanto \& Kusnadi, 2013). While the processing of non-program farmers' bokars generally immerses them in the pond before they are sold and uses freezers, not recommended such as alum, para vinegar, alum and fertilizer (Vachlepi, Nugraha, \& Alamsyah, 2016). One of the row rubber material storage processes from non-program farmers can be seen in Figure 2.

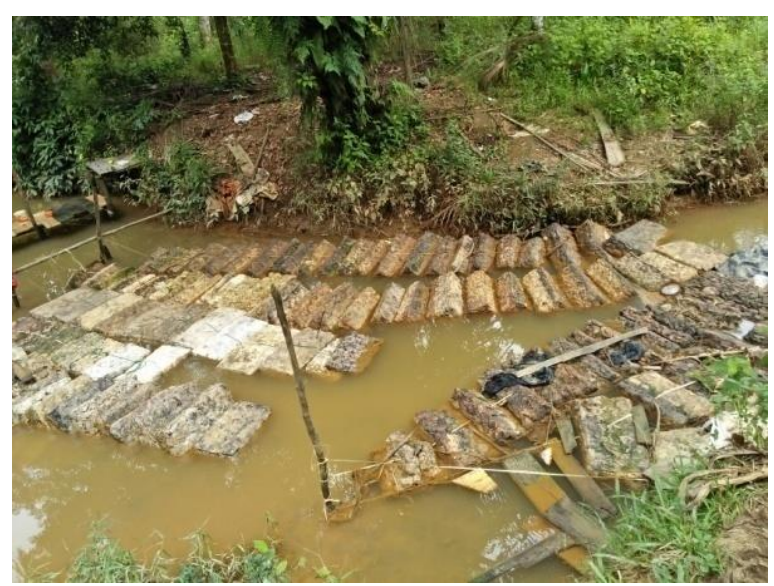

Figure 2. Row rubber material storage in farmer level.

It can be seen in Figure 1 that the storage of raw rubber material before being sold to the sword is first soaked in the pond. Soaking is done to increase the weight of bokar so that the volume of rubber is heavier than not soaked, but farmers are not aware that the price to be received by farmers will not be greater than the price of processing the rubber is good.

\section{Total production of the farmer program $\left(\mathrm{X}_{6}\right)$}

The number of rubber farmers program production is a variable that has a significant effect on farmer income (Sudjarmoko, Listyuati, \& Hasibuan, 2013). The amount of production of program farmers has more production because they already use superior seeds. The role of planting material is limited to an increase in productivity of rubber plants is quite high at around $60 \%$. The rest or around $40 \%$ is influenced by environmental factors and garden management (Boerhendhy \& Amypalupy, 2011).

\section{Number production of farmer non-program $\left(\mathrm{X}_{7}\right)$}

The amount of rubber production of nonprogram farmers has a significant effect on farmers' income. The production of non-program farmers generally uses seedling seeds so that their production only reaches $400-600 \mathrm{~kg} / \mathrm{ha} /$ year (Sagala, Suhendry, \& Azwar, 1997). So that the income of non-program farmers is lower than the program farmers because the amount of production per hectare is very much different. Productivity of rubber plants originating from seedling is up to $40 \%$ of clonal plants. Meanwhile, the productivity of clonal plants with entres originating from plant branches (no entres), has a maximum productivity of $60 \%$ from clonal plants with the source of entres derived from garden entres (Hadi, 2010).

Variables that have no significant effect on farmer income are the age of the farmer $\left(X_{1}\right)$, the rubber price of farmer non-program $\left(\mathrm{X}_{5}\right)$, fertilization of the farmer program $\left(\mathrm{X}_{8}\right)$ and the system of tapping farmer programs $\left(\mathrm{X}_{10}\right)$. The $\mathrm{X}_{1}$ variable does not have a significant effect on farmers' income, either program farmers or non program farmers. This result is in line with previous research, farmers can increase income if they have the creativity to look for other activities so that farmers' income increases (Stiawan, Wahyuningsih, \& Nurjayanti, 2014). But based on research Harwati, Supardi, \& D, (2015) states that the age variable for horticultural commodities has a significant effect because the more productive the age of the farmers, the more activities will be carried out so as to increase farmers' income. While variables $\mathrm{X}_{5}, \mathrm{X}_{8}$ and $\mathrm{X}_{10}$ did not significantly affect income because the conditions based on the conditions in the field of farmers tend to have the same behavior. 


\section{Farmer Program and Non-Program Revenue} Levels

Revenue is something that is needed by farmers to meet the needs of farmers' households. The higher the revenue, the family needs will be fulfilled. The revenue of rubber farmers at the oil and gas companies area in Musi Banyuasin can be seen in Table 5

Table 5. Program and non-program rubber farmers' revenue

\begin{tabular}{lcc}
\hline Kind of Activities & Program (IDR/month) & Non Program (IDR/month) \\
\hline Rubber & $2,800,000$ & $1,820,000$ \\
Trade & 650,000 & 629,000 \\
Etc & 250,000 & 330,000 \\
\hline Total & $3,700,000$ & $2,779,000$ \\
\hline
\end{tabular}

Based on the data above, it can be seen that the total revenue from rubber, trade and etc. Total household revenue of rubber farmers program is equal to IDR $3,700,000$ per month, whereas revenue of non program is equal IDR 2,779,000 per month. The revenue of rubber farmers program is greater than the revenue of non-program rubber farmers. Revenue from rubber is IDR 2,800,000 per month (Farmer's Program) and IDR 1,820,000 per month (Farmer's non- program). This happened because according to the previous discussion stated that there were differences in rubber prices from farmers and non-program farmers as well as the higher number of farmers produced compared to non-program farmers (Hafsah, Violetta, \& C, 2014). In addition to increased revenue, the impact of program activities can also provide a mindset of farmers to add gardens by used clonal seeds (Syarifa, Agustina, Alamsyah, \& Nugraha, 2017) and plant used land by planting intercrops (Nugraha, Alamsyah, Agustina, \& Syarifa, 2016).

\section{CONCLUSION}

Based on the discussion it can be concluded that from the 11 variables used to determine the effect on revenue, there are only 8 variables that can be analyzed further. Variables that significantly influence the income of rubber farmers at the $12 \%$ real level are the number of farmers 'rubber stands $\left(\mathrm{X}_{2}\right)$ with a significance value of 0.12 , the farmers' rubber price program $\left(\mathrm{X}_{4}\right)$ with a significance value of 0.00 , the number of production rubber farmers $\left(\mathrm{X}_{6}\right)$ with significance value of 0.00 and the amount of non-program farmer rubber production $\left(\mathrm{X}_{7}\right)$ with a significance value of 0,00 . Total Revenue farmers program IDR 3,700,000 per month and rubber farming activities contribute to revenue as much as IDR 2,800,000. While the total revenue from nonprogram farmers is equal IDR 2,779,000 per month and rubber farming activities contribute to revenue as much as IDR $1,820,000$ per month. One of the increases in revenue was due to the price of rubber received and the amount of rubber production produced was higher compared to non-program farmers. In order to increase the productivity of rubber plants, good cooperation is needed from the local government and the company to develop superior rubber plants. Besides that, it is also developing rubber nurseries because in research locations it is considered difficult to get seed breeders.

\section{REFERENCES}

A, Z., Dompak, N., \& Suprayitno. (2006). Analisis Pemasaran Bokar Suatu Kajian Terhadap Upaya Peningkatan Kesejahteraan Petani Melalui Pembenahan Tata Niaga Bokar di Provinsi Jambi. Jambi.

Agustina, D. S., Syarifa, L. F., \& Nancy, C. (2013). Kajian Kelembagaan dan Kemitraan Pemasaran Kayu Karet di Provinsi Sumatera Selatan. Jurnal Penelitian Karet2, 31(1), 5467.

Alamsyah, A., Nugraha, I. S., Agustina, D. S., \& Vachlepi, A. (2017). Tinjauan Penerapan Unit Pengolahan dan Pemasaran Bokar Untuk Mendukung Gerakan Nasional Bokar Bersih di Sumatera Selatan. Warta Perkaretan, 36(2), 159-172.

Boerhendhy, I., \& Amypalupy, K. (2011). Optimalisasi Produktivitas Karet Melalui 
Factors Effecting Revenue Level of Rubber Farmers

Penggunaan Bahan Tanam, Pemeliharaan, Sistem Eksploitasi dan Peremajaan Tanaman. Jurnal Litbang, 30(1), 23-30.

Diantoro, K., Sunarsih, \& Soejono. (2009). FaktorFaktor yang Mempengaruhi Produksi Padi pada Kelompok Tani Patemin Kecamatan Tlogosari Kabupaten Bondowoso. JurnalSEP, 3(3), 55-60.

Direktorat Jenderal Perkebunan. (2015). Statistik Perkebunan Indonesia Karet 2014-2016. Direktorat Jenderal Perkebunan.

Direktorat Jenderal Perkebunan. (2016). Statistik Perkebunan Indonesia 2015-2017 Karet. Jakarta: Kementerian Perkebunan.

Fairuzah, Z., Dalimunthe, C. I., Karyudi, Suryaman, S., \& Widhayati, W. E. (2014). Keefektifan Beberapa Fungi Antagonis (Trichoderma sp.) Dalam Biofungisida Endohevea Terhadap Penyakit Jamur Akar Putih (Rigidoporus microporus) di Lapangan. Jurnal Penelitian Karet, 32(2), 122-128.

Hadi, H. (2010). Meningkatkan Produktivitas Berbasis Mutu Fisiologis Bahan Tanam. Majalah Hevea, 2(2), 42-44.

Hafsah, F. M., Violetta, \& C, P. (2014). Analisis Pendapatan dan Tingkat Kesejahteraan Petani Karet Perkebunan Plasma Desa Sungai Hijau Kecamatan Pangkalan Banteng Kabupaten Kota Waringin Barat Kalimantan Tengah. Bogor.

Harwati, W., Supardi, \& D, A. (2015). Faktor yang Mempengaruhi Pendapatan Petani Jagung (zea mays L) Studi Kasus di Desa Sidodadi Kecamatan Patean Kabupaten Kendal. Mediagro, 11(2), 77-86.

LIPI. (2014a). Modul Diklat Jabatan Fungsional Peneliti Tingkat Pertama: Pengolahan dan Analisis Data. Cibinong: LIPI.

LIPI. (2014b). Modul Diklat Jabatan Fungsional Peneliti Tingkat Pertama: Teknis dan Praktik Pengumpulan Data Lapangan. Cibinong: LIPI.

Mepriyanto, Firdaus, T., \& Huda, N. (2015). Analisis Faktor-Faktor yang Mempengaruhi Pendapatan Petani Karet di Kecamatan Singingi Kabupaten Kuantan Singingi
Provinsi Riau. E-Jurnal Bung Hatta, 7(3), 115 .

Nazir, M. (2005). Metode Penelitan. Bogor: Ghalia Indonesia.

Nugraha, I. S., Alamsyah, A., Agustina, D. S., \& Syarifa, L. F. (2016). Faktor-Faktor Penentu yang Mempengaruhi Petani Menanam Tanaman Sela di Antara Karet di Sumatera Selatan. Jurnal Penelitian Karet, 34(1), 7788.

Nugroho, P. A., Istianto, Fairuzah, F., \& Karyudi. (2009). Pengaruh Tanaman Sela Ubi Kayu terhadap Pertumbuhan Tanaman Karet Belum Menghasilkan dan Pengurasan Hara Tanah. Jurnal Penelitian Karet, 27(1), 64-75.

Pasaribu, M. H. (2017). Analisis Faktor-Faktor yang Mempengaruhi Pendapatan Petani Karet di Desa Hasang Kabupaten Labuhan Batu Utara Sumatera Utara. Universitas Islam Negeri Sunan Kalijaga.

Sagala, A., Suhendry, I., \& Azwar, R. (1997). Produktivitas Perkebunan Karet dalam Hubungannya dengan Jenis Klon dan Agroklimat. Prosiding Apresiasi Teknologi Peningkatan Produktivitas Lahan Perkebunan Karet, 179-192.

Saptabina Usatani Karet Rakyat. (2012). Jakarta: Balai Penelitian Sembawa.

Septianita. (2009). Faktor-Faktor yang Mempengaruhi Petani karet Rakyat Melakukan Peremajaan Karet di Kabupaten Ogan Komering ULU. Jurnal Agronobis, 1(1), 130-136.

Siburian, O. (2012). Analisis Faktor-Faktor yang Mempengaruhi Ekspor Karet Alam Indonesia ke Singapura Tahun 1980-2010. Jurnal Analisis Pengembangan Ekonomi, 1(2), 1-6.

Soekartawi. (1995). Analisis Usahatani. Jakarta: Universitas Indonesia.

Stiawan, A., Wahyuningsih, \& Nurjayanti. (2014). Faktor-Faktor yang Mempengaruhi Pendapatan Petani Karet (Studi Kasus di Desa Getas Kecamatan Singorojo Kabupaten Kendal). Mediagro, 10(2), 69-80.

Sudjarmoko, B., Listyuati, D., \& Hasibuan, A. M. 
(2013). Analisis Faktor Penentu Adopsi Benih Unggul Karet. Buletin Risri, 4(2), 117128.

Sudrajat, M. (1985). Mengenal Ekonometrika Pemula. Bandung: Armico.

Syarifa, L. F., Agustina, D. S., Alamsyah, A., \& Nugraha, I. S. (2017). Dampak Pola Peremajaan Partisipatif Terhadap Perkembangan Perkebunan Karet Rakyat di Kabupaten Ogan Komering Ulu Provinsi Sumatera Selatan. Jurnal Penelitian Karet, 35(1), 71-82.

Syarifa, L. F., Agustina, D. S., Nancy, C., \& Supriadi. (2012). Evaluasi Tingkat Adopsi Klon Unggul di Tingkat Petani Karet Provinsi Sumatera Selatan. Jurnal Penelitian Karet, 30(1), 12-22.

Vachlepi, A., Nugraha, I. S., \& Alamsyah, A.
(2016). Mutu Bokar dari Kebun Petani di Areal Operasional Tambang Kabupaten Musi Banyuasin. Jurnal Standardisasi, 18(2), 8390.

Widyasari, T., \& Rinojati, N. D. (2014). Studi Pendahuluan Terhadap Karakteristik Usahatani Karet di Daerah Lingkar Tambang (Studi Kasus di Kabupaten Berau, Provinsi Kalimantan Timur. Warta Perkaretan, 33(1), 47-56.

Wiyanto, \& Kusnadi, N. (2013). Faktor-Faktor yang Mempengaruhi Kualitas Karet Perkebunan Rakyat (Kasus Perkebunan Rakyat di Kecamatan Tulang Bawang Tengah Kabupaten Tulang Bawang Lampung). Jurnal Agribisnis Indonesia, 1(1), 39-58. 